University of the District of Columbia School of Law

Digital Commons @ UDC Law

\title{
Introduction: Evolving Standards in Juvenile Justice from Gault to Graham and Beyond
}

Mae C. Quinn

University of the District of Columbia David A Clarke School of Law

Follow this and additional works at: https://digitalcommons.law.udc.edu/fac_journal_articles

Part of the Juvenile Law Commons

\section{Recommended Citation}

Mae C. Quinn, Introduction: Evolving Standards in Juvenile Justice from Gault to Graham and Beyond, 38 (macro my.short_title 1 (2012).

Available at: https://digitalcommons.law.udc.edu/fac_journal_articles/21

This Article is brought to you for free and open access by the Publications at Digital Commons @ UDC Law. It has been accepted for inclusion in Journal Articles by an authorized administrator of Digital Commons @ UDC Law. For more information, please contact lawlibraryhelp@udc.edu. 


\section{Washington University Journal of Law \& Policy}

Volume 38 Acceess to Justice: Evolving Standards in Juvenile Justice: From Gault to Graham and Beyond

2012

\section{Introduction: Evolving Standards in Juvenile Justice from Gault to Graham and Beyond}

Mae C. Quinn

Washington University School of Law

Follow this and additional works at: https://openscholarship.wustl.edu/law_journal_law_policy

Part of the Criminal Law Commons, Juvenile Law Commons, and the Law and Society Commons

\section{Recommended Citation}

Mae C. Quinn, Introduction: Evolving Standards in Juvenile Justice from Gault to Graham and Beyond, 38 WASH. U. J. L. \& PoL'Y 1 (2012),

https://openscholarship.wustl.edu/law_journal_law_policy/vol38/iss1/2

This Introduction is brought to you for free and open access by the Law School at Washington University Open Scholarship. It has been accepted for inclusion in Washington University Journal of Law \& Policy by an authorized administrator of Washington University Open Scholarship. For more information, please contact digital@wumail.wustl.edu. 


\title{
Washington University Journal of Law \& Policy
}

\section{Access to Justice: Evolving Standards in Juvenile Justice: From Gault to Graham and Beyond}

\author{
Introduction
}

\section{Mae C. Quinn*}

As suggested by the title of this symposium, the juvenile justice system is in flux. This state of transformation is nothing new, however. It is a process that has been in progress for over one hundred years. It is one that is likely to continue. And it is the topic explored in this volume by leading youth advocate-scholars who, collectively, have spent over one hundred years representing young people in juvenile courts and through law school clinical programs across the country. ${ }^{1}$

This collection of articles explores the ongoing evolution of juvenile justice standards, sharing important theoretical insights about the current state of the law as well as experience-based lessons from committed juvenile practitioners who confront important youth justice issues in our communities and courts. It is being published in conjunction with Washington University's 12th annual Access to

\footnotetext{
* Professor of Law and Co-Director, Civil Justice Clinic_-Juvenile Rights and Re-Entry Project (JR-REP), Washington University School of Law.

1. These advocate-scholars are as follows: Kristin Henning, Tamar Birckhead, Randy Hertz, and Martin Guggenheim, Lourdes Rosado, Kim McLaurin, and Sandra Simkins and Lisa Geis (with Dr. Marty Beyer) (in order of appearance in this issue).
} 
Equal Justice Colloquium, which this year sought to bring together stakeholders from the national, state, and local levels to share and build juvenile justice expertise during a day-long conference. ${ }^{2}$ Our goal was to consider where we have been, where we are now, and where we might go in the future to ensure the delivery of substantive justice for vulnerable youth, with some emphasis on the particular challenges presented by Missouri's juvenile justice system.

Most juvenile law scholars agree that the juvenile justice movement began during the Progressive Era, where reformers called upon the state as parens patriae to protect wayward children rather than punish them like adults. ${ }^{3}$ Typical of the sentiments of the day, in 1898, one child advocate declared:

We make criminals out of children who are not criminals by treating them as if they were criminals. That ought to be stopped. What we should have, in our system of criminal jurisprudence, is an entirely separate systems of courts for children ... who commit offenses which would be criminal in adults. We ought to have a "children's court" ... and we ought to have a "children's judge," who should attend to no other business. We want some place of detention for those children other than a prison. ${ }^{4}$

2. The event was sponsored by the Washington University Clinical Legal Education programs and organized by the Juvenile Rights and Re-Entry Project. Other sponsors and supporters include the Office of the Missouri the State Public Defender, the National Juvenile Defense Center, and the Gephardt Institute for Public Service. Numerous individuals also deserve thanks for helping to organize this important event, including: Katie Herr, Clinical Programs Manager; Kathryn Pierce, JR-REP Lecturer-in-Law and Supervising Attorney; and Katie Harrington and Jake Peterson, Editor-in-Chief and Managing Editor of this Journal. I am also grateful to our Fall 2011 JR-REP student attorneys Alexandra Appatova, Eric Buske, Molly Carney, Paul Cotter, Anthony Davidson, Christopher Hamilton, David Huddleston, James McFall, Hani Mirza, Hung Ou Yang, J. Benjamin Rosebrough, and William Waller for their hard work, zealous advocacy on behalf of young people, and brilliant teaching, which helped inspire the issues addressed at this Colloquium.

3. David S. Tanenhaus, The Constitutional Rights of Children: IN RE GaUlt AND JUVENILE JUSTICE 4 (2011) (describing parens patriae as "the paternalistic idea of the state as a father").

4. Anthony M. Platt, The Child Savers: The Invention of Delinquency 132 (40th Anniversary ed. 2009) (quoting Frederick Wines, Proceedings of the Illinois Conference of Charities (1898)). 
Heeding calls like these, efforts to employ new approaches in youth justice spread in the form of specialized juvenile courts. The first such institution, established in Chicago, Illinois in 1899, came to serve as a national model. ${ }^{5}$ Under this framework, young people were to be excluded from the traditional criminal justice system and instead were to receive individualized treatment in a more rehabilitative and less legalistic setting. ${ }^{6}$ The focus of this first wave of courts was described by Judge Julian Mack:

The problem for determination by the judge is not, Has this boy or girl committed a specific wrong, but What is he, how has he become what he is, and what had best be done in his interest and in the interest of the state to save him from a downward career. ${ }^{7}$

Thus the status and condition of the youth, rather than their specific behavior, called for state intervention. Judge Mack continued, "It is apparent at once that the ordinary legal evidence in a criminal court is not the sort of evidence to be heard in such a proceeding." "Instead, a "thorough investigation, usually made by the probation officer," was more important, "giv[ing] the court much information bearing on the heredity and environment of the child."

Probation investigations spanned the domain of the "psychophysical," including data about the child's mental, physical, and emotional condition, which might provide clues for the court about how to best "change ... [his or her] character." from the medical model, advocates of the juvenile court model believed it should serve as a "palliative" and "curative" institution rather than a court of law. ${ }^{11}$ Thus, treatment intervention through informality took hold in juvenile courts during the first half of the last century. ${ }^{12}$ Missouri established its first such court in $1903 .{ }^{13}$

\footnotetext{
5. TANENHAUS, supra note 3 , at 4 .

6. Id.

7. Julian W. Mack, The Juvenile Court, 23 HARV. L. REV. 104, 119-20 (1909).

8. Id. at 120 .

9. Id.

10. $I d$.

11. Id. at 122; see also PLATT, supra note 4, at 142 ("The role model for juvenile court judges was doctor-counselor.").

12. See, e.g., Cinque v. Boyd, 121 A. 678 (Conn. 1923) (describing the juvenile court
} 
Journal of Law \& Policy $\quad$ [Vol. 38:1

But as Paul W. Tappan, a contemporary commentator and scholar, observed at the time:

Despite the wide extension of a humanitarian philosophy in the child-welfare movement during the twentieth century, the treatment of the delinquent reflects a serious confusion of methods and purposes. The greatest difficulty lies in the huge gap between ideals and reality, between the realm of thought about and action toward the delinquent. It frequently appears that what most people say about the child (expressing the most benevolent intentions) has utterly no relation to what they do. Often neither what they say or do is very realistic in relation to the child's behavior and his needs. ${ }^{14}$

Tappan described a system where young people accused of a widerange of alleged wrongdoings - some acts mere youthful indiscretions not even prohibited by the criminal code-were committed to out-of-home placements such as detention centers or residential programs. ${ }^{15}$ These facilities were run by some of the same rigid rules and offered the same kind of harsh environment as adult jails and prisons. ${ }^{16}$

If not so committed, such youth often were placed on probation supervision for indefinite periods of "adjustment" time to be monitored and corrected. ${ }^{17}$ Dispositions such as these were handed down without accused children being aided by the assistance of counsel and frequently without any formal finding of guilt. ${ }^{18}$ Tappan

movement as it unfolded, collecting cases from around the country upholding the establishment of state juvenile court systems); see also Douglas E. ABRAMS, A VERY SPECIAL Place IN LifE: THE History OF JUVEnILE Justice IN Missouri (2003) (describing the evolution of juvenile justice practices in the state of Missouri).

13. ABRAMS, supra note 12, at 45-46.

14. Paul W. Tappan, Prevention and Treatment of Delinquency, in SocIAL Problems 235 (1950). Tappan was a New York University sociology and law professor who spent decades studying the workings of lower courts, including juvenile and wayward minors' courts. See id.; see also, e.g., PAul TAPPAn, Delinquent Girls in COURT: A Study of The WAyWARD Minor Court of New York (1947); PAul TAPPAN, Crime, Justice And Correction (1960).

15. Tappan, Treatment of Delinquency, supra note 14, at 236-40.

16. Id. at $236-40$.

17. Id. at $246-59$

18. Id. at $238-40$. 
argued that the efficacy of these interventions, delivered by many who were untrained in the fields of mental health or psychology, offered questionable results. ${ }^{19}$ Thus, although clearly well-intended, these localized innovations came to be seen by many as lacking fair processes, unduly paternalistic, and vulnerable to abuses of discretion. $^{20}$

Others, too, saw the emerging model as dangerous in its threat to the autonomy of impacted adolescents. Leading juvenile court critic Anthony Platt saw the institution's practices as not only class-based and condescending but also part of a state-run system of control that discounted vulnerable populations and virtually erased their personhood:

The benevolent philosophy of the juvenile court often disguises the fact that the offender is regarded as a "nonperson" who is immature, unworldly, and incapable of making effective decisions with regard to his own welfare and future. Genuine attention is rarely paid to how the offender feels and experiences his predicament;... the present structural arrangement of the juvenile court is likely to invite regression and diminish self-respect in its "clients." 21

More than this, not all youth who faced charges were provided with the option of juvenile court. Through their juvenile codes, individual states established various, sometimes conflicting, criteria that would exclude certain youth from juvenile courts' purported protective embrace. These included disparate jurisdictional age cut-offs, statutory exclusion of certain serious crimes, and discretionary rejection of children who appeared to be beyond reform. ${ }^{22}$ In 1954 ,

19. Id. at $262-76$.

20. See generally id.; PlatT, supra note 4.

21. PlatT, supra note 4, at 160.

22. See, e.g., People v. Roper, 181 N.E. 88, 90-92 (N.Y. 1932) (explaining that in the 1930s, New York youth charged with serious crimes such as first degree murder were not covered by the jurisdiction of juvenile court); State v. Monahan, 104 A.2d 21 (N.J. 1954) (describing how during the 1940s and 1950s, half the states vested juvenile courts with exclusive jurisdiction for youth under sixteen years of age); Kent v. U.S., 383 U.S. 541 (1966) (describing D.C. Code sec. 11-914, which allowed for judicial waiver after "full investigation" of any youth charged with any act that would be a felony if committed by an adult). 
the New Jersey Supreme Court offered a sketch of the wide-range of approaches:

There remain ... strongly conflicting opinions as to how juveniles should be dealt with in cases involving homicide and other heinous misconduct. Some...f fail to suggest any alternative except, perhaps, the return to the barbarous days when eight and ten-year-old boys and a 13-year-old girl were tried and executed for arson and murder. ${ }^{23}$

It went on:

Others take the view that although the juvenile court movement is soundly based and should be strengthened, it should nevertheless be confined to non-heinous offenses, at least when older children are concerned; in other words, errant children should receive supervision and correction but only so long as they have not erred too greatly. Still others, however, urge both the strengthening and widening of the juvenile court movement, pointing out that the grossness of the child's misconduct intensifies rather than lessens the need for corrective supervision under the jurisdiction of a specialist judge, empowered to protect fully both the interests of the child and the public at large. ${ }^{24}$

Thus, despite the country's alleged new orientation towards treating juveniles as a class different from adults, ${ }^{25}$ there was no clear consensus around which young people were worthy of juvenile court treatment or how that decision should be made. Countless youths therefore found themselves ushered into criminal courts to face harsh adult sentences during this period-some executed as a result. ${ }^{26}$

23. Monahan, 104 A.2d at 27.

24. Id.

25. Janet E. Ainsworth, Re-Imagining Childhood and Reconstructing the Legal Order: The Case for Abolishing the Juvenile Court, 69 N.C.L. REV. 1083, 1097 (1991) ("[T]he Progressives fashioned a discrete juvenile justice system premised upon the belief that, like other children, adolescents are not morally accountable for their behavior.").

26. See Roper, 181 N.E. at 92 (noting that a child convicted of first-degree murder, with a sufficiently guilty mind and specific intentionality, could receive the death penalty in New York in 1932); see also Thompson v. Oklahoma, 487 U.S. 815, 832 (1988) (citing to the research of Professor Victor Streib, which suggests that between eighteen and twenty juvenile were 
By the 1960s, questions and concerns about juvenile procedures and practices across the country mounted. In what might be seen as the second wave in the juvenile court movement, a new generation of youth advocates - those steeped in the teachings of the so-called due process revolution of that era-pressed for further reform in two cases before the Supreme Court. ${ }^{27}$

First, in 1966, attorneys for Morris Kent, a sixteen-year-old boy who had been transferred from the District of Columbia juvenile court system into the adult system where he faced the possibility of the death penalty for the crime of rape ${ }^{28}$ took his case to the Supreme Court. ${ }^{29}$ It was the first juvenile justice matter the high court heard. ${ }^{30}$

Kent's waiver to criminal court took place under a District of Columbia statute which allowed such discretionary determinations to be made by the judge upon "full investigation" of any youth facing felony charges. ${ }^{31}$ The investigation in Kent's case apparently took place off the record, behind closed doors, without input from Kent or his lawyer, in an ex parte exchange with juvenile court staff. ${ }^{32}$

Kent's attorneys argued that the certification order was unlawful because, among other things, "no hearing was held; because no findings were made by the Juvenile Court; because the Juvenile Court stated no reasons for waiver; and because counsel was denied access to the Social Service file which presumably was considered by the Juvenile Court in determining to waive jurisdiction."

The Court agreed and remanded for certification review. In doing so Justice Abe Fortas, writing for the Court's majority, joined the chorus of critics dubious of the fluid nature of juvenile court

\footnotetext{
executed during the first half of the last century - the same period as the first wave of the juvenile court movement).

27. See TANENHAUS, supra note 3, at 53 ("From the perspective of younger lawyers at the forefront of the 1960's due process revolution, the juvenile court was a suspect institution.").

28. Id. At the time, rape was still a death-eligible crime. See Coker v. Georgia, 433 U.S. 583 (1977) (barring execution for the crime of rape as cruel and unusual punishment). At trial, Kent was acquitted of rape based on grounds of insanity but convicted of burglary and robbery. Kent, 383 U.S. 541, 550 (1966). He was sentenced to an indeterminate term of thirty to ninety years imprisonment. $I d$.

30. See TANENHAUS, supra note 3 , at 54 .

31. Id.

32. Kent, 383 U.S at 547.

33. Id. at 552 .
} 
proceedings. He quipped that while juvenile courts were "theoretically engaged in determining the needs of the child and of society rather than adjudicating criminal conduct," "the admonition to function in a 'parental' relationship is not an invitation to procedural arbitrariness." ${ }^{34} \mathrm{He}$ went on to hold that given the critically important nature of certification proceedings, they needed to comport with due process. ${ }^{35}$ Thus, juveniles must at least be provided with access to the social file and other evidence to be considered by the court, a hearing, express findings supporting the waiver decision, and representation throughout by counsel. ${ }^{36}$

As for the role of counsel, the Court noted that while juvenile court proceedings might be informal, they should not become a "mockery" by preventing counsel from functioning as effective advocates. ${ }^{37}$ In case there was any doubt, Justice Fortas underscored the important role of juvenile defense counsel: "The right to representation by counsel is not a formality. It is not a grudging gesture to a ritualistic requirement. It is of the essence of justice." 38

Interestingly, the parties did not raise, nor did the Court address, the legitimacy of sentencing adolescents to harsh adult criminal sentences - an issue at least presented by the facts of Kent's case. ${ }^{39}$ Rather than establishing substantive limits on treating young people like adult offenders, the matter was simply handled on procedural grounds. But while it was beyond the facts of Kent's case, Justice Fortas suggested that juveniles whose cases were resolved in juvenile court might have similarly viable procedural claims:

While there can be no doubt of the original laudable purpose of juvenile courts, studies and critiques in recent years raise serious questions as to whether actual performance measures well enough against theoretical purpose to make tolerable the immunity of the process from the reach of constitutional guaranties applicable to adults. There is much evidence that

\footnotetext{
34. Id. at $554-55$.

35. Id. at $560-62$.

36. Id. at 547 .

37. Id. at 561 .

38. Id. at 561-62.

39. See generally id.
} 
some juvenile courts ... lack the personnel, facilities and techniques to perform adequately as representatives of the State in a parens patriae capacity, at least with respect to children charged with law violation. There is evidence, in fact, that there may be grounds for concern that the child receives the worst of both worlds: that he gets neither the protections accorded to adults nor the solicitous care and regenerative treatment postulated for children. ${ }^{40}$

With this pronouncement, Justice Fortas teed up the constitutional challenges of Gerald Gault, whose case was heard the following term. ${ }^{41}$ Not unlike the scene painted by Tappan in his more general critique of juvenile court practices, fifteen-year-old Gault had been sent away to a reformatory until the age of twenty-one for allegedly making lewd telephone calls to his neighbor. ${ }^{42}$ Gault and his family were not provided with legal representation or advance notice of the specific legal charges. ${ }^{43}$ Instead, they were brought in for a hearing conducted in chambers at which no evidence was presented against Gault, nor was he given an opportunity to cross-examine witnesses against him. ${ }^{44}$ Yet, Gault was required to respond to questioning by the judge about the alleged call, during which he incriminated himself in at least one fact concerning who dialed the telephone. ${ }^{45}$

Arizona law also provided no right to appeal in juvenile delinquency matters or transcript of the proceedings. ${ }^{46}$ Nevertheless, Gault sought review of his commitment to the State Industrial School by way of writ of habeas corpus. ${ }^{47}$ After the writ was denied, Gault's legal team took the case to the Supreme Court. ${ }^{48}$ Again, Justice Fortas offered a biting critique of the arbitrary and ad hoc mechanisms that had emerged in juvenile courts in disrespect of an entire class of persons-youth. In an oft-quoted line he asserted,

40. Id. at 556.

41. In re Gault, 387 U.S. 1 (1967); see also TANENHAUS, supra note 3, at 53-56.

42. Gault, 387 U.S. at 4-10.

43. Id. at 4-7.

44. Id.

45. Id. at 6-8, 43-44.

46. Id. at $8,57-58$.

47. Id. at $8-10$.

48. Id. 
"Under our Constitution, the condition of being a boy does not justify a kangaroo court." $" 49$

Pulling back the curtain on the allegedly benevolent and protective features of the courts, Justice Fortas declared that no matter how "euphemistic" the title of industrial school might be, it was still akin to incarceration and sufficiently "sentence"-like to require protections of due process before such commitment could be imposed. ${ }^{50}$ Such protections included, at least, the right to notice of the charges, right to confront the witnesses against you, and the privilege against self-incrimination. ${ }^{51}$

In addressing petitioner Gault's right to counsel claim, Justice Fortas took on the unique structure of juvenile courts, warning that juvenile probation staff - who work to screen cases and gather intake information-cannot serve as advocates for the youth. ${ }^{52}$ As law enforcement officials who might be called to testify against the child, they stand in legal conflict with them. ${ }^{53}$ The juvenile judge is similarly conflicted as the fact-finder, and cannot be called upon to protect the child's interests. ${ }^{54}$ Thus, the Court declared that the right to counsel, as a juvenile, "requires the guiding hand of counsel at every step in the proceedings against him.", 55

Thus, about fifty years into the juvenile court movement, it entered a new evolutionary phase, where the pendulum of informal proceedings swung back toward more criminal-court-like processes and features. Many youth advocates pressed for greater parallels with adult prosecutions. ${ }^{56}$ Perhaps the greatest victory on this front from the standpoint of juvenile defenders was the application of the proof beyond the reasonable doubt standard to delinquency proceedings. ${ }^{57}$

49. Id. at 28 .

50. Id. at 27.

51. Id. at 31-57. The Court left open the question of a child's right to a transcript and appeal. See TANENHAUS, supra note 3, at 99.

52. Gault, 387 U.S. at 35-36.

53. Id.

54. Id. at 36 .

55. Id. at 36-37.

56. See Tamar R. Birckhead, Toward a Theory of Procedural Justice for Juveniles, 57 BUFF. L. REV. 1447, 1456-62 (2009) (describing the movement to infuse juvenile court proceedings with more procedural rights).

57. See In re Winship, 397 U.S. 358 (1970). 
Defenders were not the only ones seeking to infuse juvenile prosecutions with more adult-like features. During what has been dubbed the "get tough" era of the 1970s to the 1990s, victims' rights groups, law enforcement officials, conservative politicians, and others again called for change to ensure more young people faced criminal court certification and harsh adult sentences. ${ }^{58}$ Consistent with this backlash against treating youth as special, the number of teens in adult correctional facilities rose from sixteen hundred in 1988 , to over nine thousand in $1997 .{ }^{59}$ And in some instances death sentences were sought and imposed on teens. ${ }^{60}$

It was in the midst of the "get tough" era that lawyers for youth pressed the Court on one of the substantive issues left aside in Kent: whether some child sentences are just too harsh to withstand Eighth Amendment scrutiny. And in 1988, the Court considered whether a sentence of death imposed against fifteen-year-old William Wayne Thompson satisfied the "evolving standards of decency" standard. ${ }^{61}$

Examining legislative provisions and the actions of juries in the preceding forty years, ${ }^{62}$ as well as noting the less developed minds of such young defendants, ${ }^{63}$ the Court determined that sentencing those under sixteen years old to death was out of step with civilized norms of a maturing society. ${ }^{64}$ However, the very next year, the Court upheld the same sentence for two different teens, a sixteen-year-old boy from Missouri, Heath Wilkins, and a seventeen-year-old Kentucky teen, Kevin Stanford. ${ }^{65}$ Deciding that their sentences were

58. See, e.g., Barry C. Feld, Race, Politics, and Juvenile Justice: The Warren Court and the Conservative 'Backlash', 87 MinN. L. Rev. 1447 (2003); Barry C. Feld, Unmitigated Punishment: Adolescent Criminal Responsibility and LWOP Sentences, 10 J.L. FAM. STUD. 11, 68 (2007); see also Perry Moriarty \& William Carson, Cognitive Warfare and Young Black Males in America, 15 IOWA J. GENDER, RACE \& JUST. (2012) (describing the 1990s "superpredator war" against young men of color within the juvenile and criminal justice systems) (forthcoming — draft on file with author).

59. See Moriarity \& Carson, supra note 58.

60. See, e.g., Thompson v. Oklahoma, 487 U.S. 815 (1988) (reviewing sentence of child who, in 1984, had been sentenced to death for a crime committed when he was fifteen-yearsold).

61. Id. at 821-23.

62. Id. at 823-33.

63. Id. at 833-37.

64. Id. at 823 .

65. Stanford v. Kentucky, 492 U.S. 361 (1989). 
in line with modern understandings of decency, the Court declined to extend the Eighth Amendment bar against imposition of the death penalty for those between sixteen and eighteen years of age. ${ }^{66}$

It appears, however, that we have turned a page in the story of juvenile justice in this country. Over the last decade, the Court has revisited its thinking of child sentencing practices. Now, its assessment is informed not only by legal considerations-like statutory changes and jury findings - but social scientific evidence that provides more concrete proof of the developmental concerns hinted at by the Court in Thompson.

In 2005, in a case involving yet another Missouri child, Christopher Simmons-perhaps suggesting that Missouri has been one the harshest outliers in youth sentencing practices - the Supreme Court finally ruled that executing anyone under eighteen violated the Eighth Amendment as cruel and unusual. ${ }^{67}$ In Roper v. Simmons, the Court again applied the evolving standards of decency doctrine, finding that the tide had turned: Emerging morality — not only in this country but internationally-abhors such treatment of children. ${ }^{68}$ In what many consider a watershed moment in the evolving story of juvenile justice in America, the Court held that youth are categorically less culpable than adults. ${ }^{69}$ Given their still maturing and developing brains, susceptibility to pressure from others, and lack of strongly formed character traits, the traditional rationales for sentencing fail to support the execution of anyone under eighteen. ${ }^{70}$

Taking this analysis to the next level, in 2010, the Court extended Roper's analysis to youth serving sentences of life without parole where they did not kill or intend to kill, noting that "developments in psychology and brain science continue to show fundamental differences between juvenile and adult minds." ${ }^{, 71}$ For some, this was a particularly noteworthy doctrinal shift as the Court applied the same evolving standards of decency test that previously had been reserved

66. Id. at 380 .

67. Roper v. Simmons, 543 U.S. 541 (2005).

68. Id. at 575 .

69. Id. at 567 .

70. Id. at 569 .

71. Graham v. Florida, __ U.S. _, 130 S. Ct. 2011 (2010). 
for death penalty cases. ${ }^{72}$ The Court found that requiring youth to spend the rest of their natural lives in prison - an extended period of imprisonment when compared to sentences of most adults-was especially harsh and warranted heightened scrutiny. ${ }^{73}$

And here is where the authors in this volume enter, into a story still very much in progress. Their contributions seek to make greater sense of this history, report on juvenile justice practices on the ground, and offer theoretical and practical suggestions for youth advocates and others in the days ahead.

In Juvenile Justice After Graham v. Florida: Keeping Due Process, Autonomy, and Paternalism in Balance, Kristin Henning helps us understand Graham's promise for youth and their advocates, situating its "categorically less culpable" framing within the larger landscape of the history of juvenile justice philosophies. However, like Tappan, she identifies pitfalls in creating a class of persons - or nonpersons-who in all respects might be seen as incompetent, warranting indiscriminate paternalistic interventions. She urges careful thinking, contextualization, and nuance in applying the teachings of Graham to ensure that we keep our potentially competing commitments to legal rights, liberalism, and child protection in check.

Picking up on the themes and warnings offered by commentators at time of the juvenile court movement's second wave, Tamar R. Birckhead shares her concerns about the modern juvenile justice system in Delinquent by Reason of Poverty. Despite the establishment of due process norms in Gault and emerging thinking offered by cases like Graham, Birckhead suggests that for some youth-particularly poor youth-juvenile court may still offer the "worst of both worlds." "74 In her rich and convincing account Birckhead warns that in making elitist assumptions about the meaning of poverty, today's justice courts may be unfairly ensnaring

\footnotetext{
72. See, e.g., Mary Berkheiser, Death is Not So Different Afterall: Graham v. Florida and the Supreme Court's "Kids are Different" Jurisprudence, 36 VT. L. REV. 1 (2011); William W. Berry III, More Different Than Life, Less Different Than Death, 71 Оніо ST. L.J. 1109 (2010).

73. Graham, 130 S. Ct. at 2028.

74. See supra note 40 and accompanying text.
} 
destitute youth, actually impeding their development and life chances.

In J.D.B. and the Maturing of Juvenile Confession Suppression Law, Martin Guggenheim and Randy Hertz provide an excellent account of the unfolding of child interrogation law in the United States-including the Supreme Court's recent decision in J.D.B. v. North Carolina. ${ }^{75}$ J.D.B., they assert, may be "a game changer in delinquency and criminal cases involving minor suspects." Analyzing how J.D.B. reflects a particularly noteworthy (re)affirmation that "kids are different," Guggenheim and Hertz argue that its application should work to change law enforcement practices and require the provision of counsel to young people prior to police questioning.

Lourdes Rosado's article, Outside the Police Station: Dealing with the Potential for Self-Incrimination in Juvenile Court, takes us below the reported-case radar to often doctrinally overlooked situations where young people may be called upon within the juvenile justice system to incriminate themselves. Rosado counsels that these scenarios, usually set in the context of juvenile court's rehabilitative features such as the intake interview and forensic evaluations, call for both litigation and legislative attention. She urges lawmakers to revise juvenile and evidence codes to protect private and potentially inculpatory information that may be elicited by system stakeholders with a view towards assisting accused youth. And until then, she urges vigilance on the part of youth advocates, calling on them to proactively protect against unnecessary disclosures and challenge their affirmative use against programmatically compliant clients.

Providing powerful pictures of continuing philosophic confusion in the juvenile justice system, the final articles in this volume spotlight systemic practices that may work to degrade and damage young people. Yet, these day-to-day practices go largely unnoticed by the law and lawyers. In Children in Chains: Indiscriminate Shackling of Juveniles, Kim McLaurin offers the views of an advocate who has worked to change laws and policies around court 
and correctional staff's use of hand and leg irons on children. Providing a survey of various state laws that address the issue, McLaurin concludes with some suggestions for reform, in part drawing on her law clinic's success in helping to change the practice of indiscriminate shackling in Massachusetts.

Finally, Sandra Simkins, with co-authors Dr. Marty Beyer and Lisa M. Geis, tackle the issue of solitary confinement for children in The Harmful Use of Isolation in Juvenile Facilities: The Need for Post-Disposition Representation. Highlighting the importance of post-dispositional representation on behalf of youth, they share the accounts of young people encountered through the re-entry representation work of Simkins's legal clinic — children who endured the hardship of long-term confinement in isolation without access to other youth, educational services, recreation, or outdoor time. Simkins and her co-authors offer a call to action and strategies for advocates seeking to end such practices.

These timely articles, and the related symposium for which this volume is named, encourage us to continue the conversation about these important topics and engage in further thoughtful and zealous advocacy on behalf of, and with, ${ }^{76}$ juveniles in this country. They also set the stage for the next part of our evolution-having looked back on Gault's impact and considered the implications of Graham's pronouncements, the thinking and sentiments shared may provide clues about what lies ahead.

In fact, the week this symposium takes place and this volume is released, the Supreme Court will hear arguments in Miller $v$. Alabama and Jackson v. Hobbs, two cases that seek to clarify the meaning of the Graham decision and extend its reasoning in the cases of two boys-ages fourteen and fifteen - each of whom were sentenced to life without parole for their roles in crimes that ultimately resulted in the loss of life. ${ }^{77}$ Evolving standards of decency

\footnotetext{
76. This author is currently writing about some of the challenges of seeking to collaborate with impacted youth - as compared to other client populations - to undertake systemic reform efforts. See Mae C. Quinn, (Im)Mobilizing Youth (work in progress).

77. See Adam Liptak, Justices Will Hear Cases of 2 Life Sentences for Youths, N.Y. TIMES, Nov. 8, 2011, at A15, available at http://www.nytimes.com/2011/11/08/us/supremecourt-will-hear-cases-of-life-sentences-for-youths.html; Legal Docket, Miller v. Alabama;
} 
in a maturing society surely suggest that sentencing youth to die behind bars without the possibility of a second chance is a chapter in our history that is ready to be closed. As was urged in 1898, we should be done making criminals - forever condemned ones at thatout of children. ${ }^{78}$

Jackson v. Hobbs, JUVENILE LAW CENTER, http://www.jlc.org/legal-docket/miller-v-alabamajackson-v-hobbs (last visited Jan. 31, 2012).

78. See supra note 4 and accompanying text. 